\title{
К ВОПРОСУ О НЕОБХОДИМОСТИ ВСТРАИВАНИЯ ПРОЦЕССА УПРАВЛЕНИЯ ПЕРСОНАЛОМ В ОБЩУЮ СТРАТЕГИЮ РАЗВИТИЯ ПРЕДПРИЯТИЙ ИНДУСТРИИ ТУРИЗМА И ГОСТЕПРИИМСТВА
}

\author{
Кочелева Светлана Борисовна, \\ магистрант Мининского университета \\ Крайнова Ольга Сергеевна, \\ канд. экон. наук, доц., зав. кафедрой туризма \\ филиал ЧОУВО «Московский университет им. С.Ю.Витте» в г.Нижнем Новгороде, \\ 2. Нижний Новгород
}

Аннотация. Данная статья раскрывает необходимость адаптации к изменяющимся условиям процедур управления персоналом туристской организации и рассматривает основные содержательные аспекты проблемы. В статье акцентируется внимание на функциях и задачах кадрового менеджмента предприятий индустрии туризма и гостеприимства.

Ключевые слова: предприятия индустрии туризма и гостеприимства, управление персоналом, кадровый менеджмент, профессионализм сотрудников, стратегия развития.

Управление любой организацией включает в себя определение целей и задач фирмы и руководство предприятием и управление людьми, работающими на данном предприятии. Удовлетворение потребностей сотрудников фирмы - одна из важнейших целей, а так же залог эффективной деятельности предприятия. Руководство турфирмы означает также и управление людьми, а именно воздействие на отношения сотрудников в направлении выполнения поставленных целей фирмы. Данные факторы особенно важны в работе туристских предприятий, так 
как туристский продукт формируется и предоставляется в присутствии клиента. Поэтому персонал туриндустрии является ключевым ресурсом, необходимым для эффективной работы предприятий сферы туризма и гостеприимства.

В настоящее время наиболее приоритетными являются вопросы обеспечения качества обслуживания туристов и повышение конкурентоспособности туристского продукта посредством эффективного построения процессов управления персоналом в субъектах туристского рынка, что предопределяет повышение требований к административноуправленческому персоналу и увеличение значимости творческого отношения к труду и высокого профессионализма работников, в особенности, линейного «контактного» персонала.

В соответствии с современной теорией и практикой управления персоналом в организации должен быть высоко развит командный дух и обеспечена вовлеченность сотрудников в решение поставленных задач совместно с высшим руководством для достижения общих стратегических целей. В рамках разрабатываемых технологий кадрового менеджмента они призваны развивать имеющиеся и формировать потенциальные способности сотрудников, мотивировать их к эффективному осуществлению конкретных функциональных обязанностей, развивать творческий потенциал. При этом творческое отношение менеджеров к управлению обуславливает повышение их самостоятельности и ответственности за выполняемую работу, активное участие их в принятии управленческих решений и непосредственную заинтересованность в результатах коллективного труда.

В связи с изменениями в экономике преобразуются и подходы в области управления человеческими ресурсами. Появляется новый тип руководителей, мышление и стиль работы которых соответствуют меняющимся задачам и условиям развития организаций. Существенно повышается и роль кадровых служб, которая ориентирована на 
достижение стратегических целей организации в части управления персоналом.

Таким образом, главная задача кадровых служб на сегодня содействие развитию бизнеса, подбор высококвалифицированных специалистов, оценка их работы, повышение их квалификации и мотивация к эффективному и качественному труду. Работа отдела персонала тесно связана с функционированием всей организации и не может быть рассмотрена как отдельная деятельность. Кадровые службы туристской организации тесно взаимодействуют с другими структурами, результатом взаимодействия которых является большая вовлеченность сотрудников в бизнес, развитие трудового потенциала каждого работника, благоприятный психологический климат в организации. В современных туристских организациях развивается система взаимодействия линейных руководителей организации разного уровня, которая обеспечивает их необходимой документацией при замещении должностей и перемещении сотрудников с одной должности на другую.

Сейчас, чтобы предложить руководству туристской фирмы рациональные решения проблем в сфере управления персоналом, появилась отдельная профессия «Менеджер по персоналу».

Менеджеры по персоналу - высококвалифицированные специалисты сферы управления человеческими ресурсами, главная задача которых - это повышение эффективности деятельности персонала организации, разработка и реализация программ развития и обучения персонала, повышение творческой активности персонала в рабочем процессе, направленном на достижение поставленных целей организации.

В соответствии с вышеизложенным можно сформулировать вывод о том, что в современной эффективной организации должна быть разработана система управления человеческими ресурсами, включающая подбор, развитие, совершенствование и мотивацию персонала, а также обеспечивающая координацию деятельности всех структур, проведение 
единой кадровой политики, подбор высококвалифицированных менеджеров, способных решать самые сложные управленческие задачи.

Следует обратить внимание так же и на планирование потребности в персонале туристского предприятия, которое связано с изменением условий хозяйствования, конъюнктурой рынка труда, повышающимся требованиям к владению знаниями и умениями сотрудников.

Кроме того, повышаются требования к самой процедуре отбора и найма персонала, основанные, во-первых, на оценке сотрудников при «входе в компанию» и, во-вторых, при выполнении ими своих функциональных обязанностей в процессе хозяйствования.

Таким образом, основная цель управления персоналом предприятия сферы туризма - это максимальное удовлетворение требований заказчика турпродукта в процессе обслуживания посредством высокого уровня квалификации менеджеров, снижение текучести кадров и увеличение производительности труда, обеспечение возможности для профессионального развития персонала, повышения его квалификации. Возможности профессионального развития внутри собственной фирмы высоко ценится ее сотрудниками, повышает мотивацию сотрудников к хорошей работе, создает благоприятный психологический климат в организации и повышает преданность сотрудников данной организации.

\section{Список литературы}

1. Крайнова О.С. Инновационные аспекты разработки логистического подхода к управлению предприятиями индустрии туризма и гостеприимства: монография. Моск. ун-т им. С.Ю. Витте; ф-л Моск. ун-та им. С.Ю. Витте в г. Н. Новгород. М.: изд. «МУ им. С.Ю. Витте». 2015. $148 \mathrm{c}$.

2. Крайнова О.С., Егоров Е.Е. Управление персоналом сферы услуг: учебное пособие. Моск. ун-т им. С.Ю. Витте; ф-л Моск. ун-та им. С.Ю. 
Витте в г. Н. Новгороде. [Электронное издание]. М.: изд. «МУ им. С.Ю. Витте». 2015. 177 с. 3,74 Мб.

3. Крайнова О.С. Проблематика управления логистическими сервисными потоками предприятий индустрии туризма и гостеприимства / B сборнике: Инновационные технологии управления. Всероссийская научно-практическая конференция. Нижний Новгород, 2014. С. 109113.

4. Севастьянова К.Д. Роль управления персоналом в повышении эффективности деятельности туристской фирмы // Молодой ученый. 2013. №3. C. 270-273.

5. Тарасова О.Ю., Сытова А.Ю., Любомудрова А.Ю. [и др.]. Менеджмент в туризме: учеб. пособие / Гл. ред. О.Ю. Тарасова, отв. ред. С.Н. Морева; М-во обр. и науки РФ, ГОУВПО «Тамб. гос. ун-т им. Г.Р. Державина». Тамбов: Издательский дом ТГУ им. Г.Р. Державина, 2011. $210 \mathrm{c}$. 